\title{
Pengaruh Gaya Kepemimpinan Transformasional dan Work Life Balance Terhadap Organizational Citizenship Behavior Pegawai Kantor Pertanahan Kabupaten Kubu Raya
}

\author{
Monaswasti Paramita May ${ }^{1}$, Ahmad Shalahuddin ${ }^{2}$ \\ ${ }^{1}$ Kantor Pertanahan Kabupaten Kubu Raya, Jl. Adi Sucipto No.79, Pontianak 78391 \\ ${ }^{2}$ Fakultas Ekonomi dan Bisnis, Universitas Tanjungpura, Pontianak 78124 \\ *Email :ahmad.shalahuddin@ekonomi.untan.ac.id
}

(Diterima Oktober 2020; Disetujui Januari 2021; Dipublikasikan April 2021)

Abstrak

\begin{abstract}
Instansi Pemerintah dalam hal ini Kantor Pertanahan Kabupaten Kubu Raya dituntut untuk dapat memberikan pelayanan kepada masyarakat secara maksimal, sehingga pegawai yang memiliki organizational citizenship behavior sangat diperlukan. Untuk itu, pihak manajemen atau pimpinan harus memperhatikan hal-hal yang dapat mempengaruhinya, antara lain gaya kepemimpinan yang diterapkan pemimpinnya dan work life balance yang dialami pegawai. Penelitian ini bertujuan untuk menguji dan menganalisis model yang berhubungan dengan pengaruh Gaya Kepemimpinan dan Work Life Balance terhadap Organizational Citizenship Behavior. Penelitian ini merupakan penelitian survey dengan tipe penelitian penjelasan (explanatory research). Populasi dalam penelitian ini adalah seluruh Pegawai Pemerintah Non Pegawai Sipil Negeri pada Kantor Pertanahan Kabupaten Kubu Raya. Jumlahresponden sebanyak 39 pegawai dengan menggunakan metode simple random sampling. Teknik analisis yang digunakan adalah Regresi Linear Berganda.

Hasil analisis regresi linear berganda menunjukkan bahwa baik gaya kepemimpinan transpormasional maupun work life balance, keduanya berpengaruh signifikan terhadap organizational citizenship behavior. Gaya kepemimpinan transformasional memiliki pengaruh yang lebih besar terhadap organizational citizenship behavior pegawai Kantor Pertanahan Kabupaten Kubu Raya.
\end{abstract}

Kata kunci : Kepemimpinan Transformasional, Work Life Balance, dan Organizationa Citizenship Behavior.

\section{PENDAHULUAN}

Kantor Pertanahan Kabupaten Kubu Raya merupakan instansi Pemerintah yang melayani kegiatan masyarakat dalam pembuatan Sertifikat Hak Atas Tanah, Peralihan Hak Atas Tanah, Pembebanan Sertifikat Hak Atas Tanah dan kegiatankegiatan pelayanan pertanahan lainnya. Pemerintah pusat melalui Program PTSL (Pendaftaran Tanah Sistematis Lengkap) telah menetapkan target penerbitan sertifikat tanah dalam 4 tahun terakhir pada Kantor Pertanahan Kabupaten Kubu Raya sebagai berikut: 1) Tahun 2016 sebesar 12.516; 2) Tahun 2017 sebesar 25.932; 3) Tahun 2018 sebesar 57.556; 4) Tahun 2019 sebesar 47.315. Tingginya target yang ditetapkan oleh Pemerintah Pusat dengan peningkatan yang signifikan setiap tahun mengakibatkan beban kerja pegawai semakin besar dan dituntut bekerja ekstra untuk menyelesaikan pekerjaan tepat waktu. Dalam kondisi demikian, perilaku 
pegawai yang mengerjakan tugas diluar perannya dan melebihi harapan atau yang dikenal dengan sebutan Organizational Citizenship Behavior (OCB) sangat diperlukan. Dalam dunia kerja yang dinamis seperti saat ini dimana tugas-tugas semakinbanyak, organisasi membutuhkan perilaku OCB yang baik seperti mengeluarkan pendapat yang konstruktif tentang tempat kerja mereka, membantu yang lain dalam timnya, menghindari konflik yang tidak perlu, dan dengan lapang dada memahami gangguan kerja yang terkadang terjadi. Mengingat banyaknya hambatan yang tidak diinginkan dalam organisasi maka perilaku OCB dapat meminimalisir terjadinya penurunan kinerja organisasi. Pegawai Kantor Pertanahan Kabupaten Kubu Raya telah menunjukkan perilaku OCB diantaranya adalah banyaknya pegawai yang rela pulang larut malam demi menyelesaikan pekerjaannya, serta masih adanya pegawai yang saling membantu dan dapat dipanggil kapan saja dibutuhkan oleh organisasi. Organization citizenship behavior (OCB) adalah suatu sikap perilaku karyawan yang dilakukan dengan sukarela, tulus, senang hati tanpa harus diperintah dan dikendalikan oleh perusahaan dalam memberikan pelayanan dengan baik (Organ, Podsakoff \& MacKenzie, 2006). Perilaku OCB pegawai dapat dikembangkan dengan kepemimpinan yang baik dalam organisasi. Kesuksesan seorang pemimpin sangat banyak dipengaruhi oleh model kepemimpinannya, yang mencakup kemampuan memimpin dan interaksi sesama pemimpin, bawahan-atasan, organisasi, serta lingkungan. Pengalaman pada diri seseorang sangat mempengaruhi cara pengambilan keputusan dan kinerja dari organisasi yang dipimpin. Sesuai dengan pendapat Robbins dan Judge (2015) bahwa organisasi yang sukses membutuhkan pekerja yang melakukan lebih dari tanggung jawab pekerjaan biasa mereka yang akan memberikan kinerja di atas harapan. Sikap ini dapat timbul dari berbagai faktor dalam organisasi, diantaranya karena adanya gaya kepemimpinan transformasional dan komitmen organisasional pegawainya yang tinggi (Robbins \& Judge, 2015). Menurut Bass dalam Yulk (2010), kepemimpinan transformasional adalah suatu keadaan dimana para pengikut dari seorang pemimpin transformasional merasa adanya kepercayaan, kekaguman, kesetiaan dan hormat terhadap pemimpin tersebut dan mereka termotivasi untuk melakukan lebih dari pada yang awalnya diharapkan. Pemimpin tersebut mentransformasi dan memotivasi para pengikut dengan cara membuat mereka lebih sadar mengenai pentingnya hasil-hasil suatu pekerjaan, serta mendorong mereka untuk lebih mementingkan organisasi atau tim daripada kepentingan diri sendiri. Kepemimpinan transformasional sangat terasa pada Kantor Pertanahan Kabupaten Kubu Raya karena dengan banyaknya beban pekerjaan yang ditanggung oleh para pegawai membuat mereka merasa lebih sadar akan tanggung jawabnya. Pimpinan selalu melibatkan bawahan pada saat pengambilan keputusan, sehingga bawahan merasa lebih dihargai dan merasa mempunyai harga diri. Menurut beberapa hasil penelitian menemukan bahwa gaya kepemimpinan transformasional berpengaruh positif terhadap OCB (Gulluce, Kaygin, Kafadar \& Atay, 2016; Irshad \& Hashmi, 2014; Lin \& Hsiao, 2014; Ismaeelzedah, Anjomshoa \& Fard, 2016; Tresna, 2016; Rahmi, 2013). Namun demikian, juga terdapat hasil penelitian yang menunjukkan hasil bahwa gaya kepemimpinan transformasional tidak berpengaruh terhadap OCB (Cofie, 2018; Maharani, Surachman, Sumiati \& Sudiro, 2017).

Sebagian besar pekerjaan Program PTSL dikerjakan oleh Para Pegawai Pemerintah Non Pegawai Negeri (PPNPN). Karena fokus pekerja banyak tercurahkanke proyek atau program tersebut maka mengakibatkan kegiatan rutin sedikit terhambat dan banyak para pemohon menjadi emosional karena permohonan mereka berjalan 
dengan sangat lambat dan bahkan baru selesai hingga bertahun- tahun. Banyaknya tunggakan yang dihadapi para pegawai seringkali membuat beban kerja semakin bertambah. Banyak para pegawai menutupi beban kerja yang banyak tersebut dengan mengerjakan tugasnya diluar jam operasional kantor. Pekerjaan tersebut dilakukan tanpa ada tambahan kompensasi dari kantor. Hal ini tentu saja akan berpengaruh pada Work life balance dari pegawai tersebut.

Work life balance atau keseimbangan kehidupan-kerja adalah suatu keadaandimana individu mampu mengatur dan membagi antara tanggung jawab pekerjaan, kehidupan keluarga dan tanggung jawab lainnya sehingga tidak terjadi konflik antara kehidupan keluarga dengan karir pekerjaan serta adanya peningkatan motivasi, produktifitas dan loyalitas terhadap pekerjaan. Work Life Balance umumnya suatu bentuk keseimbangan yang terjadi dalam kehidupan seseorang dimana mereka tidak melupakan tugas dan kewajibannya dalam bekerja tanpa harus mengabaikan segala aspek dalam kehidupan pribadinya. Menurut Zheng, et al. (2015), Pegawai yang menjalankan strategi work life balance menunjukkan kondisi kesehatan yang lebih baik dan kesejahteraan yang baik. Dengan beban kerja berat yang dirasakan olah para pegawai di Kantor Pertanahan Kabupaten Kubu Raya, mengakibatkan kerja diluar jam operasional akan menggangu keseimbangan dan kondisi kesehatan dari pegawai tersebut. Porsi di dunia kerja akan lebih banyak dari pada porsi untuk kehidupan pribadinya, sehingga menimbulkan permasalahan-permasalahan. Hal ini sejalan dengan beberapa penelitian yang menunjukkan bahwa adanya pengaruh yang signifikan dari Work Life Balance terhadap OCB (Harikaran \& Thevanes, 2018; Pradhan, Jena \& kumari, 2016). Selain itu juga terdapat hasil penelitian yang menunjukkan hasil bahwa work life balance tidak berpengaruh terhadap OCB (Makiah, Asmony \& Nurmayanti, 2018; Shakir \& Siddiqui, 2018). Oleh Karena itu, tujuan dari penelitian ini adalah untuk menguji dan menganalisis pengaruh gaya kepemimpinan transformasional dan work life balance terhadap organizational citizenship behavior (OCB) pada Kantor Pertanahan Kabupaten Kubu Raya".

\section{KAJIAN LITERATUR}

\section{Gaya Kepemimpinan Transformasional}

Gaya kepemimpinan merupakan pola menyeluruh dari tindakan seorang pemimpin baik yang tampak maupun yang tidak tampak oleh bawahannya dan gaya kepemimpinan menggambarkan dari falsafah yang konsisten, keterampilan, sifat dan sikap yang mendasari perilaku seorang. Kepemimpinan transformasional merupakan sebuah gaya kepemimpinan yang menekankan pada proses dimana orang terlibat dengan orang lain dan menciptakan suatu hubungan yang meningkatkan motivasi baik dalam diri pemimpin maupun pengikut (Northouse, 2013). Pemimpin transformasional adalah pemimpin yang menginspirasi para pengikutnya untuk bekerja keras untuk mencapai tujuan bersama, yang menaruh perhatian terhadap kebutuhan pengembangan diri para pengikutnya, mengubah kesadaran para pengikutnya (Robbins \& Judge, 2015). Kepemimpinan transformasional merupakan kepemimpinan yang menyatakan visi dengan jelas, menarik dan menjelaskan cara visi tersebut dapat dicapai, bertindak secara rahasia dan optimis, memperlihatkan keyakinan terhadap pengikut, bertindak dramastis dan simbolis untuk hal-hal penting, memimpin dan memberi contoh serta memberikan kewenangan kepada orang tertentu untuk mencapai visi tersebut (Yukl, 2010). Pemimpin 
transformasional membuat para pengikut menjadi lebih menyadari kepentingan dan nilai-nilai dari pekerjaan dan membujuk pengikutnya untuk tidak mendahulukan kepentingan diri sendiri demi organisasi. Beberapa hasil penelitian menunjukkan bahwa gaya kepemimpinan transformasional berpengaruh terhadap OCB (Jahangir, Akbar \& Haq, 2004; Budhiarti \& Nisa, 2017; Indra, Aziz \& Kornelius, 2016; Darmawan \& Maisaroh, 2017; Atmaja \& Adnyani, 2016). Hipotesis yang terbentuk adalah :

$\mathrm{H}_{1}$ : Gaya kepemimpinan transformasional berpengaruh positif terhadap OCB.

\section{Work life balance}

Work life balance didefinisikan sebagai tingkat kepuasan seseorang atas keterlibatan dirinya untuk "fit" dengan peran ganda yang dimilikinya dalam kehidupan (Lazar \& Ratiu, 2010). Work life balance berhubungan dengan adanya kesesuaian antara waktu dan usaha untuk bekerja dan menjalani aktifitas di luar pekerjaan agar mencapai kehidupan yang harmonis (Clarke dalam Lazar \& Ratiu, 2010). Work-life balance merupakan suatu kebutuhan untuk menyeimbangkan tuntutan kehidupan kerja dengan tuntutan kehidupan di luar pekerjaan sehingga dapat menjalani kehidupan yang memuaskan. Organization citizenship behavior (OCB) adalah suatu sikap perilaku karyawan yang dilakukan dengan sukarela, tulus, senang hati tanpa harus diperintah dan dikendalikan oleh perusahaan dalam memberikan pelayanan dengan baik (Organ et al., 2006).

Beberapa hasil penelitian menunjukkan bahwa work life balance berpengaruh terhadap OCB (Pradhan, Jena \& kumari, 2016; Harikaran \& Thevanes, 2018). Hipotesis yang terbentuk adalah :

\section{Organitational Citizenship Behavior}

$\mathrm{H}_{2}$ : Work life balance berpengaruh positif terhadap OCB.

Organizational citizenship behavior (OCB) menurut Robbins and Judge (2015) adalah perilaku yang dilakukan oleh seorang pegawai yang melebihi kewajiban kerja formal, namun berdampak baik karena mendukung efektivitas organisasi. Menurut Greenberg and Baron (2003), OCB adalah tindakan yang dilakukan anggota organisasi yang melebihi dari ketentuan formal pekerjaannya. Dengan kata lain, OCB merupakan perilaku yang selalu mengutamakan kepentingan orang lain, hal itu diekspresikan dalam tindakan-tindakan yang mengarah pada hal-hal yang bukan untuk memenuhi kepentingan pribadi, melainkan untuk mewujudkan kesejahteraan orang lain. Secara umum, ada tiga komponen utama OCB. Pertama, perilaku tersebut lebih dari ketentuan formal atau deskripsi pekerjaan yang telah ditentukan. Kedua, tindakan tersebut tidak memerlukan latihan (bersifat alami), dengan kata lain, orang melakukan tindakan tersebut dengan sukarela. Ketiga, tindakan tersebut tidak dihargai dengan imbalan formal oleh organisasi.

\section{METODE PENELITIAN}

Penelitian ini menggunakan metode survey, dengan objek penelitian adalah pegawai di Kantor Pertanahan Kabupaten Kubu Raya. Bentuk penelitian menggunakan bentuk penelitian kuantitatif asosiatif dan sampel sebanyak 39 responden dengan metode simple random sampling. Indikator gaya kepemimpinan transformasional merujuk pada pendapat Luthans (2006) yaitu : Kharisma, Inspirasi, Stimulasi Intelektual, dan Memerhatikan Individu. Indikator Work Life Balance merujuk pada pendapat Fisher et al. (2009) yaitu: Personal Life Interference 
Work, Work Interference Personal Life, Personal Life Enhancement of Work, dan Work Enhancement of Personal Life. Indikator Organizational Citizenship Behavior merujuk pada pendapat Luthans (2006) yaitu: Altruism, Kesungguhan, Sopan, dan Sportif. Teknik analisis yang digunakan adalah analisis Regresi linear berganda dengan menggunakan software SPSS 23.

\section{HASIL PENELITIAN DAN PEMBAHASAN}

\section{Goodness Of Fit Models}

a. Koefisien Determinasi (R2)

Dari hasil output analisis regresi dapat diketahui nilai koefisien determinasiseperti pada tabel berikut :

Tabel 1. Koefisien Determinasi

\begin{tabular}{|c|c|c|c|c|}
\hline Model & R & R Square & Adjusted R Square & Std. Error of the Estimate \\
\hline 1 &, $723^{\mathrm{a}}$ &, 523 &, 482 &, 64246 \\
\hline
\end{tabular}

Berdasarkan Tabel 1, diketahui bahwa nilai koefisien determinasi $\left(\mathrm{R}^{2}\right)$ adalah sebesar 0,523. Hal ini menunjukkan bahwa keragaman hasil prediksi OCB dijelaskan atau dipengaruhi oleh Gaya Kepemimpinan Transformasional dan Work Life Balance sebesar 52,3\% sedangkan sisanya sebesar 47,7 \% dipengaruhi oleh variabel lain yang tidak dimasukkan dalam penelitian ini.

b. Uji F

Dari hasil output analisis regresi dapat diketahui nilai F seperti pada Tabel berikut:

Tabel 2. Hasil Uji F

ANOVA $^{\mathrm{a}}$

\begin{tabular}{|ll|r|r|r|r|r|}
\hline Model & & Sum of Squares & df & Mean Square & F & Sig. \\
\hline 1 & Regression & 15,861 & 3 & 5,287 & 12,810 &, $000^{\mathrm{b}}$ \\
& Residual & 14,446 & 35 &, 413 & & \\
& Total & 30,308 & 38 & & & \\
\hline
\end{tabular}

a. Dependent Variable: OCB

b. Predictors: (Constant), K_Transformasional, Work_Life_Balance

Berdasarkan hasil uji $\mathrm{F}$ yang ditunjukkan pada Tabel 2, diketahui bahwa nilai $\mathrm{F}$ hitung sebesar 12,810 dengan tingkat signifikansi atau probabilitas 0,000<0,05. Dengan demikian dapat dikatakan bahwa persamaan regresi linear berganda yang dihasilkan dapat dipakai untuk memprediksi OCB pegawai Kantor Pertanahan Kabupaten Kubu Raya.

\section{Uji Hipotesis (Uji t)}

Dalam penelitian ini, nilai koefisien yang digunakan adalah standardized coefficients beta. Dari hasil output analisis regresi dapat diketahui nilai koefisien masing-masing variabel dapat dilihat pada tabel berikut : 
Tabel 3. Uji Hipotesis

\begin{tabular}{|c|l|c|c|c|c|}
\hline \multicolumn{2}{|c|}{ Hubungan Kausalitas } & $\begin{array}{c}\text { Standardized } \\
\text { Coefficients }\end{array}$ & \multirow{2}{*}{$\mathrm{t}$} & Sig. & Keterangan \\
\cline { 2 - 3 } & Beta & & \\
\hline 1. & $\begin{array}{l}\text { Gaya Kepemimpinan } \\
\text { Transformasional }(\mathrm{X} 1) \rightarrow \mathrm{Y}\end{array}$ &, 454 & 2,808 &, 008 & Signifikan \\
\hline 2. & Work Life Balance $(\mathrm{X} 2) \rightarrow \mathrm{Y}$ &, 378 & 2,082 &, 045 & Signifikan \\
\hline
\end{tabular}

Berdasarkan Tabel 3. di atas, maka persamaan regresi linear berganda adalah sebagai berikut :

$$
Y=0,454 X_{1}+0,378 X_{2}
$$

Persamaan regresi di atas menunjukkan bahwa :

a. Koefisien regresi variabel gaya kepemimpinan transformasional $\left(\mathrm{X}_{1}\right)$ adalah 0,454 (positif). Hal ini menunjukkan bahwa hubungan atau pengaruh gaya kepemimpinan transformasional terhadap OCB adalah positif yang berarti semakin baik gaya kepemimpinan transformasional pimpinan Kantor Pertanahan Kabupaten Kubu Raya, maka OCB pegawainya juga akan semakin baik. Selain itu juga diketahui bahwa gaya kepemimpinan transformasional memiliki pengaruh yang lebih besar terhadap OCB jika dibandingkan dengan variabel Work Life Balance. Nilai koefisien pengaruh gaya kepemimpinan transformasional terhadap OCB sebesar 0,454 (positif) dan nilai signifikansinya sebesar 0,008 $<0,05$. Hal ini menunjukan bahwa gaya kepemimpinan transformasional berpengaruh positif signifikan terhadap OCB.

b. Koefisien regresi variabel Work Life Balance $\left(\mathrm{X}_{2}\right)$ adalah sebesar 0,378. Hal ini menunjukkan bahwa hubungan atau pengaruh Work Life Balance terhadap OCB adalah positif yang berarti semakin baik Work Life Balance yang dirasakan atau dialami oleh pegawai Kantor Pertanahan Kabupaten Kubu Raya, maka OCB pegawainya akan semakin baik. Selain itu juga diketahui bahwa Work Life Balance memiliki pengaruh yang lebih kecil terhadap OCB jika dibandingkan dengan variabel gaya kepemimpinan transformasional. Nilai koefisien pengaruh Work Life Balance terhadap OCB sebesar 0,378 (positif) dan nilai signifikansinya sebesar 0,045 $<0,05$. Hal ini menunjukan bahwa Work Life Balance berpengaruhpositif dan signifikan terhadap OCB.

\section{PEMBAHASAN}

\section{Pengaruh Gaya Kepemimpinan Transformasional Terhadap OCB}

Berdasarkan hasil pengukuran validitas dan reliabilitas, diketahui bahwa keseluruhan item pernyataan masing-masing indikator yang digunakan dalam mengukur variabel gaya kepemimpinan transformasional adalah valid dan reliabel. Hal ini berarti bahwa item-item pernyataan masing-masing indikator tersebut sudah tepat digunakan sebagai pengukur variabel gaya kepemimpinan transformasional. Berdasarkan hasil output distribusi frekuensi jawaban responden, diketahui bahwa keseluruhan item masing-masing indikator memiliki nilai mean yang berada pada 
katagori baik dan sangat baik. Hal ini menjelaskan bahwa keempat indikator yang digunakan merupakan faktor penting dalam membentuk gaya kepemimpinan transformasional pimpinan Kantor Pertanahan Kabupaten Kubu Raya. Pengaruh gaya kepemimpinan transformasional terhadap organizational citizenship behavior (OCB) dapat diketahui dari nilai koefisien sebesar 0,454 dengan nilai $t$ hitung $2,808>t$ tabel 2,020 dan signifikansinya sebesar 0,008 (lebih kecil dari 0,05) dengan demikian hipotesis pertama dapat diterima. Temuan penelitian ini membuktikan bahwa gaya kepemimpinan transformasional berpengaruh signifikan terhadap organizational citizenship behavior (OCB) pegawai honorer Kantor Pertanahan Kabupaten Kubu Raya. Gaya kepemimpinan transformasional yang diukur dari jiwa kharisma atasan yang dimana atasan dapat menyampaikan visi dan misi yang jelas kepada pegawai sehingga dari hal tersebut pegawai menunjukkan sikap kesungguhannya yakni dengan menunjukkan perilaku kerja yang loyal dari pegawai biasanya. Sikap atasan yang memiliki komitmen yang dapat dipercaya pegawai menciptakan kesungguhan pegawai untuk dapat melaksanakan pekerjaan sesuai dengan prosedur kantor. Atasan yang dinilai mampu mendapatkan rasa hormat dari pegawai memberikan pengaruh terhadap sikap pegawai untuk tulus menolong dan siap memberi bantuan pada pegawai lainnya.

Sikap yang dinilai dapat menginspirasi pegawai merupakan lambang dari kesuksesan sehingga pegawai dapat menunjukkan perilaku yang porsi pegawai biasa berikan. Sikap atasan yang dapat memotivasi pegawai dan membangkitkan semangat kerja pegawai memberikan dampak terhadap sikap pegawai untuk saling menghargai pegawai lainnya dan berusaha untuk tidak membuat masalah dengan pegawai lainnya. Selain itu sikap atasan yang memerhatikan pegawai dimana atasan memberikan perhatian terhadap waktu kerja pegawai, dari hal tersebut pegawai merasa dihargai sehingga pegawai pun bersikap sopan yakni dengan menghargai orang lain dan berusaha tidak membuat masalah dengan orang lain. Sikap atasan yang memberikan nasihat untuk pencapaian prestasi kerja pegawai memberikan dampak terhadap sikap pegawai yang dapat mudah menerima kritikan orang lain dan tidak mudah untuk mengeluh dalam proporsi pekerjaannya.

Dalam penelitian ini gaya kepemimpinan transformasional memberikan pengaruh positif dan signfikan terhadap organizational citizenship behavior (OCB). Hasil penelitian ini sesuai dengan beberapa pendapat yang mengungkapkan bahwa gaya kepemimpinan transformasional memiliki pengaruh yang kuat pada kesediaan karyawan untuk terlibat dalam OCB (Jahangir et al., 2004; Gulluce, et al., 2016; Irshad\& Hashmi, 2014; Lin \& Hsiao, 2014; Ismaeelzedah, Anjomshoa \& Fard, 2016; Tresna, 2016; Rahmi, 2013; Budhiarti \& Nisa, 2017; Indra, Aziz \& Kornelius, 2016; Darmawan \& Maisaroh, 2017; Atmaja \& Adnyani, 2016). Dengan demikian, hasil penelitian ini dapat dikatakan tidak sesuai dengan hasil penelitian yang menunjukkan hasil bahwa gaya kepemimpinan transformasional tidak berpengaruh terhadap OCB (Cofie, 2018;Maharani et al., 2017).

\section{Pengaruh Work Life Balance Terhadap OCB.}

Berdasarkan hasil pengukuran validitas dan reliabilitas, diketahui bahwa keseluruhan item pernyataan masing-masing indikator yang digunakan dalam mengukur variabel Work Life Balance adalah valid dan reliabel yang berarti bahwa item-item pernyataan masing-masing indikator tersebut sudah tepat digunakan sebagai pengukur variabel Work Life Balance. Berdasarkan hasil output distribusi 
frekuensi jawaban responden, diketahui bahwa keseluruhan item masing-masing indikator memiliki nilai mean yang berada pada katagori sangat baik. Hal ini menjelaskan bahwa keempat indikator yang digunakan merupakan faktor penting dalam membentuk Work Life Balance. Pengaruh Work Life Balance terhadap Organizational Citizenship Behavior (OCB) pegawai honorer Kantor Pertanahan Kabupaten Kubu Raya dapat diketahui dari nilai koefisien sebesar 0,378 dengan nilai t hitung 2,082 > t tabel 2,020 dan signifikansinya sebesar 0,045 (lebih kecil dari 0,05 ) dengan demikian hipotesis kedua dapat diterima. Temuan penelitian ini membuktikan bahwa work life balance berpengaruh signifikan terhadap organizational citizenship behavior (OCB) pegawai honorer Kantor Pertanahan Kabupaten Kubu Raya. Work life balance yang diukur dari sikap pegawai yang bersemangat untuk melakukan berbagai hal yang diinginkannya disinyalir menciptakan sikap untuk saling tulus tolong menolong kepada orang lain yang membutuhkan dan siap memberi bantuan kepada pegawai lainnya, serta tidak mengabaikan kebutuhan pribadi meskipun terhadap tuntutan pekerjaan memberikan pengaruh yang baik dalam sikap pegawai untuk selalu siap memberikan bantuan kepada orang lain. Tidak melewatkan berbagai kegiatan pribadi meskipun banyaknya waktu yang tersita untuk pekerjaan tidak membuat pegawai mengulur serta membesarkan masalahnya. Pegawai yang merasa kehidupan pribadinya tidak menguras tenaga dalam bekerja memberikan dampak baik pegawai dalam melaksanakan pekerjaan sesuai prosedur. Pegawai yang menilai pekerjaannya menyenangkan meskipun banyak hal yang terjadi pada kehidupan pribadinya menjadi pegawai untuk selalu berusaha menghargai orang lain. Pegawai yang jarang menemui kesulitan atau merasa senang saat menyelesaikan pekerjaan di kantor bersikap untuk melaksanakan pekerjaan sesuai dengan prosedur. Pegawai yang merasa lebih baik saat di kantor karena segala hal dalam kehidupan pribadi membuat pegawai merasa untuk tidak membuat masalah dengan orang lain. Kehidupan pribadi pegawai yang dinilai memberikan kekuatan serta semangat dalam bekerja membuat pegawai tidak mudah untuk mengeluh dan tidak membesarkan masalah diluar proporsinya. Kehidupan pribadi pegawai sangat membantu dan siap untuk bekerja di hari berikutnya memberikan kesan yang baik untuk tidak mudah mengeluh. Dalam penelitian ini work life balance memberikan pengaruh positif dan singnifikan terhadap organizational citizenship behavior (OCB) pegawai honorer Kantor Pertanahan Kabupaten Kubu Raya. Hasil penelitian ini sesuai dengan beberapa penelitian yang menyatakan bahwa peningkatan work life balance secara signifikan berkontribusi untuk meningkatkan OCB karyawan dalam organisasi (Pradhan, Jena \& kumari, 2016; Harikaran \& Thevanes, 2018). Selain itu dapat dikatakan bahwa hasil penelitian ini tidak mendukung hasil penelitian sebelumnya yang dilakukan oleh Shakir \& Siddiqui (2018) dan Makiah et al., (2018) yang menunjukkan bahwa work life balance tidak memberikan pengaruh positif dan signifikan terhadap OCB.

\section{SIMPULAN}

Berdasarkan hasil analisis dan pembahasan mengenai Pengaruh Gaya Kepemimpinan Transformasional, dan Work Life Balance terhadap Organizatinal Citizenship Behavior (OCB), maka dapat disimpulkan sebagai berikut :

a. Gaya Kepemimpinan Transformasional $\left(\mathrm{X}_{1}\right)$ berpengaruh positif signifikan terhadap OCB pegawai Kantor Pertanahan Kabupaten Kubu Raya. Hasil uji 
analisis tersebut bermakna bahwa semakin baik Gaya Kepemimpinan Transformasional pimpinan, maka semakin tinggi OCB pegawai. Gaya Kepemimpinan Transformasional dalam penelitian ini menggunakan empat indikator yaitu Kharisma, Inspirasi, Stimulasi Intelektual, dan Memerhatikan Individu. Keseluruhan indikator merupakan faktor penting yang membentuk Gaya Kepemimpinan Transformasional.

b. Work Life Balance $\left(\mathrm{X}_{2}\right)$ berpengaruh positif signifikan terhadap OCB (Y) pegawaiKantor Pertanahan Kabupaten Kubu Raya. Hasil uji analisis tersebut bermakna bahwa semakin tinggi Work Life Balance pegawai, maka semakin tinggi OCB pegawai. Work Life Balance dalam penelitian ini menggunakan empat indikator yaitu Personal Life Interference Work, Work Interference Personal Life, Personal Life Enhancement of Work, dan Work Enhancement of Personal Life. Keseluruhan indikator merupakan faktor penting yang membentuk Work Life Balance.

c. Nilai koefisien Gaya Kepemimpinan Transformasional lebih tinggi daripada nilai koefisien Work Life Balance. Hal ini berarti Gaya Kepemimpinan Transformasional memiliki pengaruh yang lebih besar daripada Work Life Balance terhadap OCB pegawai Kantor Pertanahan Kabupaten Kubu Raya.

\section{REKOMENDASI}

Berdasarkan hasil penelitian ini, dapat diberikan rekomendasi antara lain pimpinan hendaknya dapat memunculkan ide-ide kreatif yang dapat membangun prestasi kerja sehingga dapat memberikan gagasan yang menarik untuk diterapkan kepada pegawai. Selain itu, pegawai hendaknya diberikan keleluasan dalam bekerja dengan tetap memprioritaskan kebutuhan pribadi agar pegawai merasakan beban kerja yang rileks.

\section{DAFTAR PUSTAKA}

Atmaja, I K.A.W., \& Adnyani, I G.A.D. (2016). Pengaruh Gaya Kepemimpinan Transformasional dan Komitmen Organisasional Terhadap Organizational Citizenship Behavior. Vol. 5, No. 11, ISSN: 2302-8912.

Budhiarti, A.A. dan Nisa, Y.F. (2017). The Effect Of Religiusity, Tranformational Leadership And Demography On Organizational citizenship behavior (Ocb). JP3I. Volume VI No. 2

Cofie, A.R. (2018). Relationships Between Transformational Leadership and Organizational Citizenship Behavior in Ghanaian Organizations. Walden University. http://scholarworks.waldenu.edu/dissertations.

Darmawan, A. dan Maisaroh. (2017). Pengaruh Kepemimpinan Transformasional Dan Kepuasan Kerja Terhadap Organizational citizenship behavior Pada Islamic Boarding School Tingkat SMA di Yogyakarta. Jurnal Aplikasi Bisnis, Vol.17 No.2. p-ISSN: 1411-4054/e-ISSN: 2579-3217.

Fisher, G.G., Bulger, C.A., and Smith, C.A. (2009). Beyond work and family: a measure of work/nonwork interference and enhancement. Journal of Occupational Health Psychology. Vol. 14. No. 4, 441-456.

Ghozali, Imam. (2016). Aplikasi Analisis Multivariete Dengan Program SPSS 23 (Edisi 8). Cetakan ke VIII. Semarang: Badan Penerbit Universitas Diponegoro. 
Greenberg, J., \& Baron, R.A. (2003). Behavior in Organizations (Understanding And Managing The Human Side Of Work ). Eight edition, Prentice Hall.

Gulluce, A.C., Kaygin, E., Kafadar, S.B. \& Atay, M. (2016). The Relationship between Transformational Leadership and Organizational Commitment: A Study on the Bank Employees. Journal of Service Science and Management, Vol 9. 263275, JSSM: 2016.93033.

Harikaran, S., \& Thevanes, N. (2018). The Relationships among Work-Life Balance, Organizational Citizenship Behavior and Organizational Performance: A Review of Literature. Journal of Business and Management. e-ISSN: 2278487X, p-ISSN: 2319-7668. Volume 20, Issue 8. Ver. V, PP 25-31.

Indra, B.A., Aziz, I., \& Kornelius, Y. (2016). Pengaruh Gaya Kepemimpinan Transformasional, Transaksional, Kepuasan Kerja Terhadap OCB Karyawan PT. Konstrindo Putera Perkasa. Jurnal Ilmu Manajemen Universitas Tadulako. Vol. 2, No. 1, Januari 2016, 027-038. ISSN; 2443-1850.

Irshad, R., \& Hashmi, M.S. (2014). How Transformational Leadership is Related to Organizational Citizenship Behavior? The Mediating Role of Emotional Intelligence. Pakistan Journal of Commerce and Social Sciences. Vol. 8 (2), 413- 425.

Ismaeelzadeh, M.R., Anjomshoa, M.R., and Fard, M.K. (2016). Effect of Transformational Leadership on Organizational Citizenship Behavior in Physical Education Teachers in Mashhad. Global Journal of Scientific Researches. Vol. 4(5), pp. 86-90, E-ISSN: 2311-732X.

Jahangir, N., Akbar, M.M, \& Haq, M. (2004). Organizational Citizenship Behavior: Its Nature And Antecedents. Brac University Journal. Vol. I, No. 2, 2004, pp. 7585.

Lazar, I., and Ratiu, P. (2010). The Role of Work-Life Balance Practices in Order to Improve Organizational Performance. European Research Studies, Vol. XIII, Issue (I).

Lin, R.S.J., and Hsiao, J.K. (2014). The Relationships between Transformational Leadership, Knowledge Sharing, Trust and Organizational Citizenship Behavior. International Journal of Innovation, Management and Technology, Vol. 5, No. 3.

Luthans, F. (2006). Perilaku Organisasi. Edisi Sepuluh, PT. Andi: Yogyakarta.

Maharani, V., Surachman, Sumiati dan Sudiro, A. (2017). The Effect of Trnasformational Leadership on Organizational citizenship behavior Mediated by Job Satisfaction and Organizational Commitment (Study at Islamic Bank in Malang Raya). International Journal of Ekonomic Research Vol. 14, N0. 3. ISSN : 0972-9380.

Makiah, Asmony, T., \& Nurmayanti, S. (2018). Effect Of Work life balance, Workplace Spirituality of Organizational citizenship behavior (OCB) Through Organizational Commitment As Intervening Variables (Study On Teacher Generation Y In Islamic Boarding School District West Lombok, Indonesia). International Journal of Economics, Commerce and Management. Vol. VI, Issue 7, ISSN : 23480386.

Northouse, Peter G. (2013). Kemimpinan; Teori dan Praktik. Jakarta: PT. Gramedia Pustaka.

Organ, D.W., Podsakoff, P.M., \& MacKenzie, S.B. (2006). Organizational citizenship behavior: Its nature, antecedents, and consequences. Thousand Oaks, CA: Sage 
https://books.google.co.id/books?hl=id\&lr=\&id=wXiHCgAAQBAJ\&oi=fnd\&p= PP1\&dq=organizational+citizenship+behavior:+its+nature,+antecedents,+an $\mathrm{d}+$ consequences + pdf.

Pradhan, R.K., Jena, L.K., \& Kumari, I.G. (2016). " Effect of Work-Life Balance on Organizational citizenship behavior : Role of Organizational Commitment". Journal of Global Business Review, Vol. 17 (3S). 15S-295.

Rahmi, B.M. (2013). Pengaruh Kepemimpinan Transformasional Terhadap Organizational Citizenship Behavior dan Komitmen Organisasional dengan Mediasi Kepuasan Kerja. Tesis. Program Pascasarjana Universitas Udayana. Denpasar.

Robbins, Stephen P. dan Judge, Timothy A. (2015). Perilaku Organisasi. Jakarta: Salemba Empat.

Shakir, K., \& Siddiqui, S.J. (2018). The Relationship Between Work-Life Balance Initiatives and Organizational citizenship behavior: The Mediating Role of Perceived Organizational Support. JISR-MSSE. Volume 16. No. 2.

Sugiyono. (2014). Metode Penelitian Pendidikan Pendekatan Kuantitatif, Kualitatif, dan R\&D. Bandung: Alfabeta.

Tresna, P.W. (2016). The Influence of Transformational Leadership to Organizational Citizenship Behavior with Job Satisfaction as Mediator Variable. Review of Integrative Business \& Economics Research. Vol. 5 (2). ISSN: 2304-1013.

Yulk, Gary. (2010). Kememimpinan dalam Organisasi, Edisi Kelima, Jakarta; PT.Indeks.

Zheng, C., Molineux, J., Mirshekary, S., \& Scarparo, S. (2015). "Developing Individual and Organizational Work-Life Balance Strategies to Improve Employee Health and Wellbeing". Employee Relations. Vol. 37. No. 3 pp. 354-379. 